\title{
Italian Migration Policies in Times of Crisis: The Policy Gap Reconsidered
}

\author{
Tiziana Caponio \\ Teresa M. Cappiali
}

\begin{abstract}
Numerous studies have shown that there is a structural gap between restrictive migration policies and expansive inflows in democratic countries; yet scholars have not yet sufficiently reflected on how this gap is shaped in times of crisis. Focusing on the case of Italy in the years between 2007 and 2017, this article aims to answer the following research questions: How have the different challenges triggered by economic and humanitarian crises affected the gap between restrictive policies and expansive outcomes in Italy? Which actors have shaped this gap? Our analysis reconsiders the two dominant hypotheses in the literature-the 'client politics' and the 'embedded liberalism' hypotheses - by showing how in the last decade the migration policy gap in Italy has not been the result of pressure by actors in the economic and liberal norm spheres, but rather reflects conflictual relationships within the political-institutional sphere between Italian governments and EU institutions.
\end{abstract}

Keywords: Migration policy gap, Economic Crisis, Humanitarian Crisis, Politicalinstitutional actors, Italy

\section{Introduction}

In the last decade, immigration policies in Italy, as in other European countries, have evolved in a context of overlapping crises. The outbreak of the financial crisis, which started in 2008, followed, in 2011, by the massive arrival of migrants and refugees as a result of the 'Arab Spring' and the war in Libya, led to a particularly awkward conjuncture for Italian migration policies and to the perception, in public opinion, of an unprecedented emergency.

According to migration scholars, migration policies in democratic countries are characterized by a structural gap between stated goals and their outcomes. While justification for restrictive policies resides in the principle that liberal states have the right to control their borders and to choose who to admit, the sovereignty of the state is challenged in at least in two ways. 
First, according to the 'client politics' hypothesis, the control gap is the result of pressure exerted by organised groups in receiving societies with interest in migration, particularly employers' organizations, who benefit most from expansive policies (Freeman 1995). Second, the 'embedded liberalism' hypothesis suggests that liberal states are constrained in their capacity to adopt and implement restrictive policies by their liberal constitutions, as well as by the international treaties and supra-national institutions they adhere to (Hollifield 2000; Soysal 1994). In particular, actors who mobilise to protect civil rights, such as NGOs, trade unions, and social movements, as well as judicial courts, play a key role by pressing the state to comply with migrants' rights. The first hypothesis relates to what scholars call the 'economic sphere', while the second concerns the 'sphere of liberal norms' (Guiraudon \& Lahav 2006). Taken together, the actors involved in these two spheres greatly influence states' decisions on migration. Furthermore, research that looks at the impact of economic crises on migration patterns suggests that inflows are not stopped by restrictive policies, but change their composition, with family members and asylum seekers replacing immigrant workers. This leads to an overall expansion of the migrant population, despite states' efforts to control migration (Castles 2004; Castles \& Vezzoli 2009).

Despite the important contribution of the literature mentioned above, scholars have not looked closely enough at how the structural gap of migration policies is shaped in times of crisis. Focusing on the case of Italy in the years between 2007 and 2017, this article aims to answer the following research questions: How have the different challenges triggered by economic and humanitarian crises affected the structural gap between restrictive policies and expansive outcomes in Italy? Which actors have shaped this gap?

We explain that overall migrant stocks and inflows have increased moderately in the past decade, with asylum seekers replacing immigrant workers. This reconfigured policy gap, we argue, is not the result of pressure by actors in the economic and liberal norm spheres, but reflects 
contradictions within what we call the 'political-institutional sphere,' that sees the emergence of conflictual relationships between Italian governments and EU institutions. Our analysis, therefore, reconsiders the two hypotheses that are deemed crucial to understanding the policy gap, and looks at the role political and institutional actors play in reconfiguring migration policies in times of crisis. In order to support our analysis, we combine secondary literature and first-hand data, including Italian and European Statistics (e.i. ISTAT, Ministry of the Interior, Eurostat), European Surveys (i.e. Eurobarometer), official Italian and European websites and documents (i.e. Ministry of the Interior and European Commission), reports of NGOs and international organizations, and national newspapers.

In the next section, we provide a background on Italian migration policy and on the actors that affected the migration gap before the financial crisis. In the second section, we describe the development of migration policies and migration flows throughout the last decade. In the third section, we focus on changing interests and goals within the three main spheres of action that shape migration policy - the economic, liberal norms and political-institutional spheres. In the conclusion, we elaborate on how our analysis of the case of Italy contributes to a general understanding of the development of migration policies in times of crisis.

\section{The Structural Gap Between 1990s and early 2000s}

In the 1990s and early 2000s, migration flows into Italy developed in a context characterized by a latent, increasingly relevant, demand for low-skilled workers in a segmented labour market, which offered foreigners non-qualified and informal jobs in sectors such as domestic and personal care services, agriculture, retail and wholesale trade, hotels and catering, and construction (Reyneri 2008, p. 113). As a consequence, Italian migration laws, since their first formulation, have been characterized by a structural gap between formally restrictive measures 
and lenient implementation, especially vis-à-vis undocumented migrants. Overstaying on a tourist visa was a common practice, encouraged by periodic mass regularisations (or amnesties) that allowed immigrant workers to regularize their status. As well, a considerable number of migrants arrived in a clandestine manner, by sea, as in the case of inflows from Albania in the 1990s, or by crossing land borders with Slovenia and Austria (Colombo \& Sciortino 2004).

Despite the Italian government's stated goals of controlling immigration and reducing irregular immigration, both regular and irregular inflows continued to grow. With the introduction of the Turco-Napolitano Law (Law no. 40/1998) in 1998 and the Bossi-Fini Law (or Law n. 189/2002) in 2002 in particular, the structural gap widened. ${ }^{1}$ These two laws established more restrictive controls. Moreover, the Bossi-Fini Law, which claimed to be tougher on undocumented migrants, made the status of legally resident migrants more precarious (for details see: Caponio \& Graziano 2011; Triandafyllidou \& Ambrosini 2011; Calavita 2005). Yet, these laws launched two mass amnesties, de facto contradicting their restrictive goals. In 1998 the Turco-Napolitano Law regularised around 217, 000 migrants, and in 2002 the Bossi-Fini allowed the greatest regularization in Italian history, with a total of around 650,000 regularisations (Finotelli \& Arango 2011).

In her account of migration policy-making processes in Italy, Zincone (2011) explains the structural gap by examining what she calls the 'powerful lobby of the weak', formed by a 'strange alliance' between three main actors: (1) employers' organisations supporting the interests of small and medium sized firms; (2) Catholic NGOs that mobilised on behalf of Italian families, emphasizing a discourse that looked at migrants, and specifically migrant women, as a crucial resource to help families to carry out their multiple care tasks (for children, the elderly, etc.); and (3) trade unions, which have supported migrants' inclusion in economic and social rights, and promoted their regularisation. According to Zincone, employers' organisations and 
Catholic NGOs were particularly effective in putting pressure on the centrist Catholic parties of the Second Berlusconi Government (2001-05) to introduce the amnesty (see also: Zaslove 2006).

Zincone's analysis of Italian migration policies provides evidence for both the 'client politics' and the 'embedded liberalism' hypotheses, showing how the economic and the liberal norm spheres are not mutually exclusive. The 'powerful lobby of the weak', she showed, brought together employers and families in need of migrant workers for their firms or their dependent family members, with trade unions and NGOs and, to some extent, legal courts that aimed to protect migrants' rights.

Below, we turn our attention to the Italian migration policy gap in the decade 2007-17, looking at external and internal controls.

\section{Assessing the Gap in Times of Crisis. Policies and Migration Flows in 2007-17 \\ Increasingly restrictive policy}

According to Brochmann and Hammar (1999), migration policies include two types of controls: internal controls, which take place within the receiving country, and external controls, which operate at the border or before the migrants' arrival. As we shall see below, in Italy in the decade between 2007 and 2017, both types of policies have been profoundly affected, first by the economic crisis, and then, from 2011 on, by the humanitarian crisis.

In Italy, similarly to other European countries (Roos \& Zaun 2016), the economic crisis did not mark a turn in migration policies, but rather strengthened the restrictive path already taken with the 2002 Bossi-Fini Law (see above). More specifically, in the period 2007-2011, internal controls developed in two directions: criminalisation of undocumented migrants and more selective amnesties. The first point was at the centre of the action of the Fourth Berlusconi 
Government (2008-2011). Laws no. 125/2008 and 94/2009, known together as the 'Security Package' (Pacchetto Sicurezza), reinforced measures for the expulsion of irregular migrants (Triandafyllidou \& Ambrosini 2011) and introduced the controversial 'entrance and irregular residence crime', which set a fine at between 5,000 and 10,000 euros, to be paid by the migrant who committed the felony. Those who did not comply with the expulsion order, and were caught again in an irregular status, could be punished with imprisonment of up to a maximum of five years.

As for regularisations, two new amnesty measures were introduced in 2009 and 2012, each establishing more selective criteria than had been the case in the past. The 2009 regularisation applied only to migrants working in the care sector (Colf e Badanti), while the 2012 regularisation, introduced in the midst of the economic crisis (Decree no. 109), while not limited to a specific employment category, set very demanding criteria for employers, i.e., as well as the payment of a 1,000 Euros slum sum, they had to provide proof of having paid the foreign worker regularly for at least 6 months.

Since 2008, external controls became more restrictive as well, both in terms of admission policies, which decide who can be admitted to the territory and under which conditions, and of border patrols, which aim to keep the unauthorised out. Since the Turco Napolitano Law, the number of allowable entries was based on annual quotas which, although they were always set below labour market needs (Triandafillydou \& Ambrosini 2011, p. 253), continued to increase until 2008, when - as shown in table 1 - they started to be considerably reduced.

\section{[Table 1 here]}


Simultaneously with the freeze in quotas for work purposes, patrols at sea were strengthened. Already, in 2002, the Bossi-Fini Law had given border police the power to stop undocumented migrants - but not asylum seekers - and 'push them back' (respingimenti alla frontiera, art. no. 10 of the Law no. 189/2002). Furthermore, beginning in 2000, agreements had been made with Tunisia (2003 and 2009) and Libya (in 2000, 2003, 2004, 2005 and 2008), to strengthen the capacity of those countries to patrol their coasts and, in the case of Tunisia, to collaborate with Italy in the identification and re-admission of undocumented Tunisian citizens. In 2008, the Bengasi Treaty with Muammar Gaddafi stipulated that Libya would have to accept all migrants leaving its coasts and expelled from Italy, allowing direct push back from international waters (Cuttitta 2017, p. 30).

However, with the fall of the Zine El-Abidine Ben Ali regime in Tunisia in January 2011, and the ouster of Gaddafi in the March of the same year, this system of external controls collapsed. In Tunisia, the crisis officially ended on April 5, 2011, when a new agreement was signed with the transition government, ${ }^{2}$ but in Libya the situation deteriorated during the prolonged civil war. External controls continued to be enacted by the Italian Constant Vigilance operation, which had been patrolling the Strait of Sicily since 2004, and then by the Mare Nostrum operation in October 2013, which pursued both security and humanitarian goals by contributing to the Libyan Search and Rescue Area (SAR) (for details see: Cuttitta 2017; Pastore \& Roman 2014). In November 2014, when Mare Nostrum came to an end, the EU agency Frontex (European Border and Coast Guard Agency) launched Triton, supported by 29 countries but less well-funded, i.e. 2,9 million Euros per month against the 9,9 of Mare Nostrum. This corresponded with the more limited mandate of Triton, which was centred on border control, and not on rescue. In April 2015, however, after the death of 700 migrants in a rescue operation carried out by a commercial vessel, the EU tripled the budget of Triton, allowing for the 
extension of intervention in the Libyan SAR, and launched a new military operation, Eunavfor Med Sophia, tasked with disrupting smuggling networks and boats leaving from Libya (Cuttitta 2017, p. 7).

The humanitarian crisis affected also internal controls, with attention shifting from restrictions on migrant workers to unauthorised migrants and asylum seekers. According to the Dublin Convention of 1990, and the following Dublin II (2003), and Dublin III (2013) Regulations, the country of first entry has the responsibility of fingerprinting the migrant and examining his/her asylum application. To oversee and strengthen the enforcement of these Regulations in Italy and Greece, the 'European Agenda on Migration' (COM2015/240), adopted by the EU Commission in May 2015, introduced hotspots, i.e. first aid and reception centres where identification procedures and fingerprinting of newly-arrived migrants take place, as well as preliminary assessment of those who may be entitled to refugee status; officials from Frontex, Easo (European Asylum Support Office), Europol (European Police Office) and Eurojust (EU Judicial Cooperation Unit) work together with the Italian police.

In April 2016, when Libya's newly-established Government of National Accord was formally acknowledged by the UN, conditions for returning to the pre-2011 regime of externalised controls were - at least provisionally - restored. In February 2017, Italy signed a new treaty with Libya and provided 10 patrol boats to the Libyan coast guard (Cuttitta 2017, p. 17). Furthermore, on April $12^{\text {th }}$ new restrictive internal control measures were introduced by the Minniti-Orlando Decree (Decree no. 13, in 2017). This Decree expanded the role of the CIE (Centres of Identification and Expulsion - Centri di Identificazione e Espulsione) - now renamed CPR (Centres of Permanence and Repatriation- Centri di Permanenza e Rimpatrio) - in the migrant reception system in an effort to speed up repatriation for those considered ineligible for 
international protection. It also established that asylum seekers cannot appeal in ordinary courts if their applications are rejected.

\section{Slower growth of stock and inflows}

From the end of the 1990s and throughout the 2000s, the number of immigrants living in Italy grew significantly, making Italy's growth rate one of the highest in Europe (IOM 2010, p. 121). To give an idea, in 1998 there were 991,678 immigrants residing in Italy, in 2002 there were 1,334,889, and in 2007 there were 3,432,651 (ISMU 2016). Focusing on the period after the financial crisis of 2008, Table 2 indicates that the number of migrants regularly residing in Italy continued to grow, except in 2011, when we can observe a significant reduction of the stock. The increase was primarily in non-EU migrants, although EU citizens make up 38.4 per cent of the increase, indicating the effect of the inclusion of Romania and Bulgaria in the EU. Overall, in 2015 the migrant stock amounted to 5,026,153, reflecting a moderate increase, compared to the previous decade: while the total growth rate between 1998 and 2007 was 246.1 per cent, between 2008 and 2015 the growth rate decreased to 29.1 per cent.

\section{[Table 2 here]}

Table 3 presents an overview of the total number of new inflows, and the percentage of non-EU immigrants entering Italy each year per reason of entry. One can observe the numbers growing in the two years following the economic crisis, with a 37.3 per cent increase in 2009 and a 34.3 per cent increase in $2010 .{ }^{3}$ However, these numbers rapidly decline thereafter, with a reduction of 65.5 per cent in 2011 and 37 per cent in 2012. 
Furthermore, as shown in Table 3, throughout the 2007-15 period there was a considerable change in the composition of migrants. While work permits accounted for between 50 and 60 per cent of the total permits released each year between 2007 and 2010, starting in 2011, they started to decrease, reaching the lowest percentage in 2015 (9.1 per cent). On the other hand, in 2011 the number of migrants coming for family reasons increased, reaching 44.8 per cent of the total population arriving in Italy in 2015. Migrants arriving for humanitarian reasons increased as well. Between 2007 and 2010 these latter represented only 3.7 per cent of the total; beginning in 2011 this number increased, reaching a peak of 28.2 per cent in 2015. Finally, permits released for educational reasons also increased slightly, moving from an average of 4 per cent between 2007 and 2010 to roughly 9 to 12 per cent between 2011 and 2015 .

\section{[Table 3 here]}

To sum up, the data on inflows indicate a progressive reconfiguration of the types of permits released, suggesting that the economic and the humanitarian crises have played a major role in re-shaping the composition of migrants entering into the country. After the financial crisis, the reduction of quotas and the less attractive Italian labour market reduced the number of migrant workers entering for work purposes (see also ISMU 2016). However, as shown in figure 1, the number of asylum applications has significantly increased since the beginning of the humanitarian crisis in 2011, reaching a peak in $2015 .^{4}$

\section{[Figure 1 here]}


Another important consideration is the number of migrants living in Italy without stay permits. According to the Fondazione ISMU (2012), immediately following the economic crisis there was a reduction of irregular stock in Italy. In January 2011, there were estimated to be around 443,000 migrants without work permits, and in 2012, around 326,000. However, estimates increased again in the following years, reaching 350, 000 in 2013, 404,000 in 2014, and 435,000 in 2015 (ISMU 2016, p. 19). There is reason to believe that a significant number of the irregular population arrived in Italy without documents and remain either unable or unwilling to obtain stay permits (Ibid.). However, statistics on border apprehension of non-authorised entries show a reduction of migrants registered, from 24,528 in 2004 to 7,713 in 2013 (Caritas/Migrantes 2014, p. 124-125). Moreover, there has been a decrease in the number of people repatriated (from 35,437 in 2004 to 8,769 in 2013) and of people who failed to comply with an order of expulsion (from 45,697 in 2004 to 13,529 in 2013) (Caritas/Migrantes 2014, p. 125).

However, this moderate expansion of the presence of migrants, both legal and undocumented, in the last decade does not correspond with Italians' perceptions. Data from the Eurobarometer show a decrease in concerns about migration right after the financial crisis in 2008, but they increased again starting in 2014, when the refugee crisis was unfolding, reaching 42 per cent in the fall of $2016 .^{5}$ Surveys addressing the issue of migration in-depth suggest deteriorating attitudes towards in the more recent years. For instance, according to research conducted by Demos in April 2016, 41 per cent of the interviewees were concerned about migration. This percentage represented an increase by 10 points since April 2010 (see Diamanti 2016, p. 9). Furthermore, according to research conducted by YouGov in October 2016, 52 per cent of Italians believed that there were 'too many foreigners' and said that this did not 'make [them] feel at home'. ${ }^{6}$ 
Media representation of the migration crisis as a sudden and totally unpredictable emergency has contributed to the spread of unfavourable attitudes (Barretta \& Milazzo 2016, p.30). Before the financial crisis, an emphasis was put on the link between migration and crime; in more recent years, the emphasis has shifted to unplanned arrivals, immigrants' reception and health risks, conveying the idea of an unprecedented 'invasion' and a major 'threat' to the country's security and wellbeing (Barretta \& Milazzo 2016, p. 16).

\section{Accounting for the Gap. An Analysis of Migration Policymaking}

In this section, we look at how the interests and logics of action of the actors involved in policymaking processes on migration have evolved in the 2007-17 period. First, we analyse the evolution of the spheres of economy and of liberal norms that dominated migration policymaking in the period before the financial crisis. Subsequently, we examine the political-institutional sphere, to show how it has become crucial in times of crisis. The actors we identify below are not the only actors involved in the policy-making processes, but they represent the most important ones in Italy.

\section{The sphere of economy}

Since the end of the first decade of the 2000s, the economic interests that supported the expansion of migration inflows in previous decades became progressively less interested in new entries and regularisations of undocumented migrants. The liberalisation of the labour market for Romanian and Bulgarian citizens in 2007, and the rising levels of unemployment caused by the economic crisis, made it easier for small and medium sized firms, as well as for families in need of caregivers, to hire EU migrants in the underground economy or third-country nationals who already lived in Italy and needed to renew their work permits. As shown by Anastasia, Gambuzzo 
\& Rasera (2013, p. 146), with the outbreak of the financial crisis, employers, especially in the service sectors, did not stop recruiting, but primarily hired migrants who were already present in the territory and who had lost jobs in the sectors most affected by the crisis (e.g. manufacturing and construction). For instance, in 201342.7 per cent (or 1,526,850) of unemployed immigrants were hired the same year (Ibid.) Of these, only one fifth, or 18.7 per cent, were hired for the first time. The remaining 81.3 per cent had held regular jobs in the country before 2013 (see also: Caritas/Migrantes 2016).

Since 2011, with the unfolding of the humanitarian crisis and the developing of system of migrant reception centred upon the discretional power of the Prefects at the local level (see below; for details: Caponio \& Cappiali 2017; Bassi 2016), two categories of actors emerged to the fore as having an interest on migration: (1) small and medium sized businesses in the touristic hospitality sector that have been converted, at the request of the Prefectures, into reception centres for asylum seekers; and (2) NGOs and cooperatives that specialise in running these centres and related services. The 35-euro fee paid by the Ministry of the Interior for each asylumseeker has helped small hotels in areas of low touristic attractiveness to survive (see for instance: Dal Zotto (2016) on the Lombardy valleys); and, the need for more specialised services and second-level accommodation has spurred the emergence of new cooperatives and non-profit organisations, generating a positive spill-over in the local labour market, especially for young people in the economically disadvantaged areas in the South of Italy (Bassi 2016).

This 'industry of migration', as it is provocatively called by the media (Verga 2017) has come into the spotlight because of episodes of exploitation and crime, such as the Mafia Capitale scandal and the case of the Asylum Seekers Reception Centre (CARA) of Mineo. ${ }^{7}$ Some cooperatives and improvised associations, especially in Southern regions such as Campania, Sicily and Calabria, have been denounced by NGOs for packing large numbers of people in 
preposterous facilities, like country cottages or pizzerias, located far away from urban centres, making the migrants easy prey for illegal work in the countryside (Cittadinanza Attiva 2016; Medu 2016). In fact, agricultural businesses in the South of Italy seem particularly keen to employ undocumented migrants at very low pay to keep their products competitive. Journalistic reports and judicial inquiries have also found connections between the exploitation of undocumented migrants in the South and criminal organisations (see for instance Bulfon 2017).

The economic sphere has thus been profoundly reshaped by both the economic and the humanitarian crises. Those who take advantage of new inflows are now either linked to the chaotic and highly localised system of asylum seeker reception, as in the case of the hotels and the cooperatives contracted to provide services, or they are close to criminal organisations, as is the case of the unlawful agricultural employers in the South of Italy. Compared with the economic actors who mobilised in decades past, the new actors in the economic spheres represent an extremely fragmented and particularistic assemblage of interests with little political influence.

\section{The sphere of liberal norms}

Traditionally, the sphere of liberal norms in Italy has been mainly shaped by trade unions, NGOs and judicial courts (Zincone 2011; Ambrosini 2013). The trade unions and NGOs have been deeply affected by the recent economic and humanitarian crises. First, the main Italian trade unions, in particular, have usually had positive attitudes towards immigrant workers and have mobilised in favour of their access to social and political rights (Mottura, Cozzi \& Rinaldini 2010). However, during the economic crisis they largely kept silent on the greater difficulties and increasing discrimination - migrants encountered in the labour market (Cappiali 2015 and 2016). Moreover, as migrants are increasingly hired in sectors that are less protected and nonunionized, that are part of the underground economy, trade unions have become increasingly 
powerless to fight for their protection. In the vacuum left by the trade unions, new and old actors of the radical left organizations — such as radical trade unions and the grassroots organizations of many social centres - have stepped in to help migrants organize against exploitation (Cappiali 2015, p. 72). However, these actors are quite weak and fragmented, mobilised at the local level, but with little national influence.

Secondly, the electoral defeat of centre-left and Catholic moderate parties, and the prominent role assumed by the Lega Nord in the Forth Berlusconi Government (2008-11), weakened the political leverage of NGOs at the end of the 2000s. Furthermore, the humanitarian crisis triggered two new developments: professionalisation (Ambrosini 2017) and internationalisation. Nation-wide NGOs, like the Red Cross or Caritas, have become the main subcontractors of reception services for asylum seekers, both at a national and local levels. In addition, new cooperatives and third-sector organisations have sprung up and quickly begun to specialise in these services, competing for EU and national funding. As for internationalisation, with the end of the Mare Nostrum operation, and the more limited mandate of Triton in terms of search and rescue (see above), international NGOs, like the newly-founded Migrant Offshore Aid Station (MOAS), or the more established Médicins Sans Frontières, Oxfam, Save the Children etc., have started to mobilise to help migrants in danger in the Mediterranean Sea (Cuttitta 2017).

These developments have led to the de-legitimation of NGOs. Along with the scandals and cases of corruption mentioned in the section on the economic sphere, reports of overcrowded and mismanaged reception centres have emerged, involving well-known Catholic organisations like the Confraternita della Misericordia, as in the case of the Lampedusa Centre (Tizian 2017). Moreover, because Frontex (2017) accused the international NGOs of encouraging migrant trafficking, and investigations were initiated by the Court of Palermo, their rescue operations come into the media spotlight. The restored responsibility of Libyan authorities for international 
waters, and the introduction, in August 2017 by the Italian Ministry of the Interior in consultation with the European Commission (Ministry of the Interior 2017c) of a 'Code of conduct for the NGOs operating in the rescue of migrants at sea' (Codice di condotta per le ONG impregnate nel salvataggio dei migranti in mare), have further de-legitimised the NGOs presence in the area, and raised questions about the humanitarian nature of their mission. ${ }^{8}$

Finally, the Italian courts, invested with constitutional review powers, have reversed some of the most controversial norms around undocumented migrants during the Fourth Berlusconi Government (2008-11) (Triandafillydou \& Ambrosini 2011). The measures introduced with the Security Package in 2008 and 2009 are a case in point. In July 2010, for instance, the Constitutional Court declared that art. no. 1 (par. 1) of Law no. 94/2009- which increased the severity of punishment for felonies committed by undocumented migrants-was unconstitutional, on the basis that punishment must only be proportional to the seriousness of the felony (Sentence no. 249, 8 July 2010). However, the same Court did not rule against the so-called 'penalty of illegal entry and stay', on the basis that border control and limitation of migratory inflows are of crucial interest to the state. Moreover, as the humanitarian crisis has unfolded, Italian courts have, in many cases, reversed rejected asylum applications, enabling many asylum seekers to remain in Italy (Vassallo Paleologo 2015).

Not only the Italian courts, but the European Court for Human Rights (ECHR) and the national courts of other EU countries have also frequently ruled in favour of migrants' rights, overturning or questioning some of the more restrictive Italian and European rules. In 2012, for instance, the ECHR ruled against Italy for the push-back of 24 Eritrean and Somali migrants carried out in $2009,{ }^{9}$ putting an end to the practice of collective pushback operations, from international waters to Libya, that were systematically carried out throughout 2009 and 2010 (Cuttitta 2014, p. 30). Furthermore, courts in Germany, Norway, Switzerland and the UK have 
severely criticized the poor quality of migrant reception services, and some have also blocked the transfer of asylum seekers back to Italy (Bongioanni 2012), as in the case of Tarackhel vs. Switzerland, where the ECHR suspended the transfer of an Afghan family to Italy because of the lack of guarantees on the conditions of reception. ${ }^{10}$

The political-institutional sphere. Bringing the EU in?

So far, we have shown how the overlap of the economic and the humanitarian crises have affected the spheres of the economy and liberal norms. In this context, several actors in the political-institutional sphere have become more prominent: whereas at the beginning of the economic crisis domestic political and administrative actors were essentially the key players, with the development of the humanitarian crisis, EU political institutions expanded their influence. In particular, the European Commission has become increasingly involved in the enforcement of restrictive EU asylum policy in Italy, following the securitization approach underlying the decisions taken by the European Council.

As mentioned above, the outbreak of the economic crisis in 2008 provided a window of opportunity for the Lega Nord to strengthen anti-migration legislation. This approach was consistent with a more general EU orientation of restricting inflows from African countries while relaxing visa requirements for citizens of prospective EU member states - Poland (which entered the EU in 2003), Romania and Bulgaria (2007) (Finotelli \& Sciortino 2013). However, the goals and relations of actors within the institutional sphere started to change dramatically in the context of the humanitarian crisis. Vis-à-vis the collapse of both the Tunisian and the Libyan regimes, the restrictiveness of then Lega Nord Minister of the Interiors, Roberto Maroni, was seriously challenged. While the door continued to be officially closed for economic migrants (see the reduction of entry quotas in Table 1), the government assumed a more open discourse towards 
humanitarian migrants, emphasising, however, the need for sharing responsibility at the EU level (Tucci 2011).

Facing the humanitarian crisis, the Italian government adopted what can be called a 'blind eye' approach, pursuing two interconnected strategies: turning migrants towards other EU countries, and devolving responsibility of matters of reception to the local level. Both strategies were evident since the beginning. In February 2011, when a massive number of unexpected arrivals came from Tunisia, Minister Maroni declared the so-called 'North African Emergency' (Decree of the President of the Council of the Ministries of February 12, 2011). Some of the migrants were sent to a temporary camp set up in the region of Apulia, and most of them ran away (Corriere.it 2011). Despite Minister Maroni's promise that only asylum seekers would be accommodated by the regions, ${ }^{11}$ while undocumented migrants would be held in detention centres and repatriated to Tunisia, in the end he opted for the exact opposite strategy. Following an agreement signed with the Tunisian government on April 5, all Tunisian migrants who arrived before that date were granted humanitarian permits, while expulsion would only be applied to those who arrived afterwards. This decision was criticised by French authorities (Corriere.it 2016).

The 'blind eye' approach continued to be used by following governments, i.e. the Monti technical Government (2011-12), the centre-left Letta (2013-14) and Renzi Governments (201416). The enforcement of internal controls, i.e., per EU regulations, fingerprinting and identification, was considerably relaxed. In fact, after the launch of the Mare Nostrum operation in October 2013, information on screening and identification procedures became less transparent and accessible (Pastore \& Roman 2014, p. 23), drawing harsh criticism from other European countries, and leading the EU Commission to start an infringement procedure against Italy (together with Greece and Croatia) in December 2015 (European Commission 2017). 
The 'blind eye' approach shaped also the implementation of reception policies. In 2002 the Bossi-Fini Law introduced the Protection System for Asylum Seekers and Refugees (SPRAR), which was designed to coordinate reception measures between the Ministry of the Interior, UNHCR and the national Association of Italian municipalities (ANCI). Yet, by declaring a state of emergency in 2011, and by prolonging it until February 2013, the Italian government established a parallel system based on Extraordinary Reception Centres (CAS, Centri di Accoglienza Straordinaria). These were managed in an extremely discretional manner by the National Civil Protection Department and, beginning in 2013, the Prefectures, leading to the development of a reception system characterised by high costs and strong regional differentiation in the services provided (Giovannetti 2013; Marchetti 2012), not even counting episodes of criminal activity. ${ }^{5}$ Furthermore, as pointed out in judgements by courts in various EU countries and by the ECHR (see above), the poor quality of the reception facilities led many migrants to leave Italy, de facto deflecting the issue to other European countries.

The intervention of the EU, and in particular of the Commission and the Council of Ministers, since May 2015, has worked to counter this 'blind eye' approach and restore security within the Schengen area, in order to avoid the reintroduction of internal borders on the part of most Central and Northern European countries. ${ }^{12}$ The securitization approach, which has been the basis of the EU migration agenda since the early 1990s (Guiraudon 2003), has been pursued in two concrete ways: through direct intervention in overseeing controls in the Mediterranean, as indicated by the above-mentioned Triton and Eunavfor Med Sophia operations; and by ensuring the enforcement of migrant identification procedures on the Italian soil through the establishment of hotspots.

The European Agenda on Migration pursued an additional goal, i.e. that of allowing for the redistribution of asylum seekers in Europe. The initial proposal of the Commission was to create 
a compulsory mechanism of distribution, on the basis of pre-agreed shares of asylum seekers, but the agreement among Member States instead provided for a voluntary system, leaving responsibility for determining its own quota to each state. ${ }^{13}$ Furthermore, the relocation quota provided for by the agreement was extremely low, i.e. 24,000 asylum seekers in two years, and applied exclusively to nationalities with a high probability of getting access to international protection, like Somalis and Eritreans. In practice, the main result of EU intervention was a considerable increase in the percentage of migrants whose fingerprints have been included in the Eurodac database upon arrival, from $36 \%$ in September 2015 to $78 \%$ in January 2016, ${ }^{14}$ indicating the success of the 'hotspot approach'. However, this put more pressure on the Italian reception system, since those who are identified there cannot apply for international protection elsewhere, leading to the perception of a never-ending state of crisis (Caponio \& Cappiali 2017).

Thus, in times of crisis the political-institutional sphere seems to take the lead, yet it does not mean an automatic reduction in the migration policy gap. The gap was reduced during the years of the economic crisis, reflecting the convergence of the Italian government's and EU institutions' restrictive agendas; however, during the humanitarian crisis, these agendas became increasingly divergent. Whereas the 'blind eye' approach at a national level lead initially to a new increase in the number of entries of undocumented migrants, at a EU level the securitarian policy agenda called for direct intervention in the field in Italy - and Greece - in order to reduce the gap and restore 'compliance with the pacts'.

\section{Conclusion}

In this article we have examined how the Italian structural gap between restrictive migration policies and expansive inflows has evolved in the 2007-17 decade, vis-à-vis the awkward conjuncture of the economic and humanitarian crises. We showed how, during the financial 
crisis, Italian policies successfully curtailed new inflows; however, with the humanitarian crisis in 2011, and the collapse of the system of external controls, the number of undocumented migrants started to raise again and a major reconfiguration of inflows took place, from foreign workers to asylum seekers. Our analysis suggests that, rather than a 'structural gap', in times of crisis we observe an oscillation between the closure and opening of migration policies, and therefore a reconfiguration of the categories of migrants entering the country that mirrors the loopholes in such policies.

To account for this oscillation, we have investigated the actors involved in migration policy-making. Our conclusions speak to both the 'client politics' and 'embedded liberalism' hypotheses. As regards the former, our analysis of the Italian case shows how groups with an interest in migration are not immutable over time, but are likely to be deeply affected by by the changing context in times of crisis. As regards the 'embedded liberalism' hypothesis, our analysis demonstrates that supranational institutions do not necessarily represent a 'liberal constraint' for national governments, but can also promote restrictive policies (see also: Guiraudon and Lahav 2006), as demonstrated by the intervention of EU institutions during the humanitarian crisis in Italy. Furthermore, the actors in the sphere of liberal norms have been affected by the overlapping crises: trade unions encounter greater difficulty mobilising in favour of migrants, and developments in the field of NGOs, like professionalisation and internationalisation, have challenged their traditional, solidaristic bases of social legitimacy. The courts, in turn, have acted ambivalently, sometimes ruling in favour of migrants, other times ruling against them, even while expressing concern for respecting their rights.

What stands out is how crucial the role of political institutions - i.e. the actors with the responsibility for deciding migration policy - is in times of crisis. Relations within this politicalinstitutional sphere can shape the migration policy gap in different ways: whereas during the 
economic crisis the coincidence of the interests and goals of Italian governments and EU institutions favoured the enforcement of restrictive policies that were effective in constraining new inflows, in the context of the humanitarian crisis these agendas clearly started to diverge. If the Italian government opted for a 'blind eye' approach to avoid politicisation, EU institutions, namely the European Commission and the European Council, concerned with adhering to the Schengen Agreement, privileged the introduction of restrictive measures to be implemented - at least in principle - in collaboration with Italian authorities (i.e. Triton and the hotspots), leaving aside actions aimed at strengthening solidarity in migrants' reception among Member States.

In this conflictual scenario, public opinion polls showing a deterioration in attitudes towards migrants open the political space to a more straightforward politicisation of the issue. The current political strategies of the Lega Nord and the 5Stars Movement are clear cases in point. On the one hand, the Lega Nord, with the new leader Matteo Salvini, has put less emphasis Northern regions' interests, while attempting to turn in a radical right, anti-EU and antiestablishment, national party (Diamanti 2017). The 5Stars Movement, on the other hand, on September 2017 elected as candidate premier for the national political elections Luigi Di Maio, who has distinguished for his campaign against NGOs in the Mediterranean Sea (repubblica.it 2017). Moreover, the demise of actors in the sphere of the economy and the de-legitimation of those in the sphere of liberal norms have dismantled the 'powerful lobby of the weak'. Without allies in the Italian political spectrum, and an increasingly aggressive anti-migration discourse on the part of old and new populist parties, the weak are doomed to become even weaker.

\section{References}

Ambrosini, M. (2013) 'Fighting discrimination and exclusion: civil society and immigration policies in Italy', Migration Letter, vol. 10, no. 3, pp. 313-323. 
Ambrosini, M. (2017) 'Why irregular migrants arrive and remain: the role of intermediaries', Journal of Ethnic and Migration Studies, vol. 43, no. 11, pp. 1813-1830.

Anastasia, B., Gambuzza M., \& Rasera M. (2013) 'Stranieri nei mercati del lavoro. L'impatto della crisi', in Stranieri e disuguali. Le disuguaglianze nei diritti e nelle condizioni di vita degli immigrati, eds C. Saraceno, N. Sartor, \& G. Sciortino, Il Mulino, Bologna, pp. 111148.

Barretta, P. \& Milazzo G. eds (2016) Notizie oltre i muri. Quarto rapporto. Carta di Roma. http://www.cartadiroma.org/wp-content/uploads/2016/12/Rapporto-2016_cartadiroma_EMBARGATO-FINO-ALLE-13-DEL-1912.pdf

Bassi, M. (2016) 'Les acteurs non-étatiques face à l'immigration en Sicile et à Lampedusa', Après-demain, vol. 39, no. 3, pp. 36-92.

Bongioanni, M. (2012) 'Rifugiati, l'Italia "bacchettata" anche da una Corte britannica', la Repubblica.it, 2 November, available online at: http://www.repubblica.it/solidarieta/dirittiumani/2012/11/02/news/rifugiati_1_italia_bacchettata_anche_da-45793290/

Brochmann, G. \& Hammar T. (1999) Mechanisms of Immigration Control: A Comparative Analysis of European Regulation Policies, Berg, Oxford.

Bulfon, F (2017) 'Il capolarato non si ferma: basta sikh, I nuovi schiavi nei nuovi campi sono i migranti' L'espresso, 2 August, available online at: http://espresso.repubblica.it/attualita/2017/08/01/news/il-caporalato-non-si-ferma-bastasikh-i-nuovi-schiavi-nei-campi-sono-i-migranti-1.307303

Calavita, K. (2005) Immigrants at the Margins. Law, Race, and Exclusion in Southern Europe, Cambridge University Press, Cambridge.

Camilli, A. (2017) 'Tutte le accuse contro l'ong Jugend Rettet', Internazionale.it, 8 August, available online at: https://www.internazionale.it/notizie/annalisacamilli/2017/08/08/accuse-ong-iuventa-jugend-rettet

Caponio T. \& Cappiali T.M. (2017) 'La perdurante questione dei rifugiati: tra ipocrisia organizzzata, solidarismo e crescente protesta,' in Politica in Italia. Edizione 2017. I fatti dell'anno e le interpretazioni, eds. A. Chiaramonte \& A. Wilson, Il Mulino, Bologna, pp. 189- 208.

Caponio, T. \& Graziano P. R. (2011) 'Towards a Security-Oriented Migration Policy Model? Evidence from the Italian Case', in Migration and Welfare in the New Europe, eds. E. Carmel, A. Cerami, T. Papadopoulos, The Policy Press, Bristol, pp. 105-120.

Cappiali, T. M (2015) 'Activism and Participation Among People of Migrant Background: Discourses and Practices of Inclusiveness in Four Italian Cities.' Political Science. Doctoral diss., Unpublished, Université de Montréal, Montreal, https://papyrus.bib.umontreal.ca/xmlui/handle/1866/13579

Cappiali, T. M. (2016) 'Activism of Immigrants in Vulnerable Conditions and Radical-Left Allies: A Case Study of Italy's Struggle of the Crane', Journal of Ethnic and Migration Studies, vol. 42, no. 15, pp. 2508-2527.

Caritas/Migrantes (2016) Dossier Statistico Immigrazione 2016, Anterem, Rome. Caritas/Migrantes (2014) Dossier Statistico Immigrazione 2014, Anterem, Rome. 
Carli, A. (2017) 'Ora i migranti puntano su Tunisia e Algeria per raggiungere l'Italia', Il sole 24 ore.com, 7 September, available online at: http://www.ilsole24ore.com/art/notizie/201709-07/ora-migranti-puntano-tunisia-e-algeria-raggiungere-1-italia144339.shtml?uuid=AEd8AEPC

Castles, S. (2004) 'The factors that make and unmake migration policies,' International Migration Review, vol. 28, no. 3, pp. 852-884.

Castles, S. \& Vezzoli, S. (2009) 'The global economic crisis and migration: temporary interruption or structural change?', Paradigmes, 2, June 2009.

Cittadinanza Attiva (2016) 'InCAStrati. Iniziative civiche sulla gestione dei centri di accoglienza straordinaria per richiedenti asilo', available online at: http://www.cittadinanzattiva.it/files/primo_piano/giustizia/inCAStrati-report.pdf

Colombo, A. \& Sciortino G. (2004) 'Italian immigration: the origins, nature and evolution of Italy's migratory systems', Journal of Modern Italian Studies, vol. 9, no. 1, pp. 49-70.

Corriere.it (2011) 'L'emergenza immigrati. Nuovi arrivi a Manduria ma i migranti fuggono in massa dalla tendopoli', 1 April, available online at: http://www.corriere.it/cronache/11_aprile_01/lampedusa-migranti-arrivi-puglia_f6dfcb485c27-11e0-b06c-b43ad3228bba.shtml?refresh_ce-cp

Cuttitta, P. (2017) 'Repoliticization Through Search and Rescue? Humanitarian NGOs and Migration Management in the Central Mediterranean', Geopolitics, DOI: 10.1080/14650045.2017.1344834

Cuttitta, P. (2014), 'From the Cap Anamur to Mare Nostrum: Humanitarism and migration controls at the EU's maritime borders' in The Common European Asylum System and Human Rights: Enhancing protection in times of emergency, eds. Matera C. \& Taylor A., Centre for the Law of European External Relations Working Papers 2014/7, pp. 21-37.

Dal Zotto, E. (2016) 'L'Emergenza Nord Africa a Bergamo, Pavia e Mantova. Politiche e discorsi nella dimensione locale dell'accoglienza', in Immigrazione e contesti locali. Annuario CirMib 2016, ed. M. Colombo, Vita e pensiero, Milano, pp. 265-278.

Diamanti, I. (2016) L'invasione mediale degli immigrati senza volto, in Notizie oltre i muri, In eds P. Barretta \& G. Milazzo Notizie oltre i muri. Quarto rapporto. Carta di Roma. http://www.cartadiroma.org/wp-content/uploads/2016/12/Rapporto-2016_cartadiroma_EMBARGATO-FINO-ALLE-13-DEL-1912.pdf

Diamanti, I. (2017) 'Padania addio, la lega adesso è il partito di Salvini', Reppublica.it, 22 May, available online at: http://www.repubblica.it/politica/2017/05/22/news/padania_addio_la_lega_adesso_e_il_p artito_personale_di_salvini-166051677/?ref=RHPPRB-BH-I0-C4-P1-S1.4-T1

European Commission (2017) 'Infringement decisions: Implementation of Common European Asylum System; Hungarian asylum legislation', available online at: https://ec.europa.eu/home-affairs/what-is-new/news/news/2015/20151210_3_en

Finotelli, C. \& Arango J. (2011) 'Regularization of undocumented immigrants in Italy and Spain: determinants and effects', Documents d'Anàlisi Geogràphica, vol. 57 no. 3, pp. 495-515. 
Finotelli, C. \& Sciortino G. (2013), 'Through the Gates of the Fortress: European Visa Policies and the Limits of Immigration Control', Perspectives on European Politics and Society, vol. 14 , no. 1 , pp. 80-101.

Freeman, G. P. (1995) 'Modes of Immigration Politics in Liberal Democratic State.' International Migration Review, vol. 29, no. 4, pp. 881-902.

Frontex (2017) 'Risk Analysis for 2017', available online at: http://frontex.europa.eu/assets/Publications/Risk_Analysis/Annual_Risk_Analysis_2017.pd $\underline{\mathrm{f}}$

Giovannetti, M. (2013) L'infinita emergenza, Anci-Cittalia, Rome.

Guiraudon, V. (2003) 'The Constitution of a European Immigration Policy Domain: A Political Sociology Approach,' Journal of European Public Policy, vol. 10, no. 2, pp. 263-282.

Guiraudon, V. \& Lahav, G. (2006) 'Actors and venues in immigration control: Closing the gap between political demands and policy outcomes,' West European Politics, vol. 29, no. 2, pp. 201-223.

Hollifield, J. (2000) Migration and the 'New' international order. The missing regime, in B. Ghosh (ed.), Managing Migration. Time for a new international regime? Oxford University Press, Oxford, pp. 75-109.

ISMU (2012) Diciottesimo rapporto sulle migrazioni 2012, Franco Angeli, Milan.

ISMU (2016) The Twenty-second Italian Report on Migrations 2016, Franco Angeli, Milan.

ISTAT (2016a) 'Cittadini non comunitari: presenza, nuovi ingressi e acqusizioni di cittadinanza', available online at: http://www.istat.it/it/files/2016/09/Cittadini-non-comunitari_2016.pdf

ISTAT (2016b) 'Permessi di soggiorno per asilo politico e protezione umanitaria. Anni 20152016', available online at: https://www.istat.it/it/files/2016/12/Report-PermessiSoggiorno2015-2016.pdf?title=Permessi+di+soggiorno+e+asilo+politico+$+23 \% 2 \mathrm{Fdic} \% 2 \mathrm{~F} 2016+-+$ Testo+integrale+e+nota+metodologica.pdf

LasciateCIEntrare (2016) '\#20giugnoLasciateCIEntrare', available online at: www.lasciatecientrare.it/j25/attachments/article/230/Report\%2020GiugnoLasciareCIEntr $\underline{\text { are.pdf }}$

Malagutti, V. \& S. Vergine dalla Valletta (2017) 'Moas, tutti i misteri del fondatore della ONG', L'Espresso, 11 May, available online at: http://espresso.repubblica.it/plus/articoli/2017/05/08/news/chi-e-davvero-il-fondatore-dimoas-e-dove-finiscono-i-soldi-raccolti-1.301015

Marchetti, C. (2012), 'Assistiti o segregati? I grandi centri per richiedenti asilo in Italia', La società degli individui, vol. 14, no. 41, pp. 57-70.

Medu (2016) 'Asilo precario. I Centri di Accoglienza Straordinaria e l'esperienza di Ragusa', available online at: http://www.mediciperidirittiumani.org/pdf/MEDU_Rapporto_CAS_26_aprile_FINALE.p $\underline{\mathrm{df}}$

Ministry of the Interior (2017a) 'I dati dell'asilo', available online at: http://www.libertaciviliimmigrazione.dlci.interno.gov.it/it/documentazione/statistica/inumeri-dellasilo 
Ministry of the Interior (2017b) 'Cruscotto statistico giornaliero', available online at: http://www.libertaciviliimmigrazione.dlci.interno.gov.it/it/documentazione/statistica/crusc otto-statistico-giornaliero

Ministry of the Interior (2017c) 'Codice di condotta per le ONG impregnate nel salvataggio dei migranti in mare', available online at: http://www.interno.gov.it/it/serviziline/documenti/codice-condotta-ong-impegnate-nel-salvataggio-dei-migranti-mare

Mottura, G., Cozzi S. \& Rinaldini M. (2010) Uscire da Babele. Percorsi e problemi del rapporto tra sindacato e lavoratori immigrati, Ediesse, Rome.

Pastore, F. \& Roman, E. (2014) 'Implementing Selective Protection. A comparative Review of the Implementation of Asylum Policies at National Level Focusing on the Treatment of Mixed Migration Flows at EU's Southern Marine Borders', Working Papers FIERI, available online at: http://fieri.it/wpcontent/uploads/2014/11/WP_FIERI_FINAL_Implementing-Selective-

Protection_PastoreRoman_Oct-20141.pdf

Repubblica.it (2017) 'Migranti, Di Maio: "Ipocrita chi difende le ong”. Replica: Saviano: "Cerca voti di chi li vuole morti", 23 April, available online at: http://www.repubblica.it/politica/2017/04/23/news/di_maio_saviano_ong-163704617/

Reyneri, E. (2008) 'Italy', in Permanent or Circular Migration? Policy Choices to Address Demographic Decline and Labour Shortages in Europe, eds E. Hönekopp \& H. Mattila,, IOM, Budapest, pp. 109-148.

Roos, C. \& Zaun, N. (2016), 'The global economic crisis as a critical juncture? The crisis's impact on migration movements and policies in Europe and the US', Journal of Ethnic and Migration Studies, vol. 42, n. 10, pp. 1579-1589.

Soysal, Y. N. (1994) Limits of Citizenship: Migrants and Post-National Membership in Europe, University of Chicago Press, Chicago.

Stasolla, C. (2017) 'Ong taxi del mediterraneo: Di Maio fa insinuazioni senza dare soluzioni', Ilfattoquotidiano.it, 23 April, available online at: http://www.ilfattoquotidiano.it/2017/04/23/ong-taxi-del-mediterraneo-di-maio-fainsinuazioni-senza-dare-soluzioni/3538861/

Trindafyllidou, A. \& Ambrosini M. (2011) 'Irregular Immigration Control in Italy and Greece: Strong Fencing and Weak Gate-keeping serving the Labour Market', European Journal of Migration and Law, vol. 13, no. 3, pp. 251-273.

Tizian, G. (2017) 'Lampedusa, ecco come Mr Accoglienza rubava sui migranti', L'Espresso.it, 8 June, available online at: http://espresso.repubblica.it/attualita/2017/06/08/news/Lampedusa-ecco-come-MrAccoglienza-rubava-sui-migranti-1.303545

Tucci, C. (2011) 'Maroni: A Lampedusa è emergenza umanitaria. Impensabile che l'Europa stia solo a guardare', Ilsole24ore.com, 16 February, available online at: http://www.ilsole24ore.com/art/notizie/2011-02-16/maroni-lampedusa-emergenzaumanitaria-160307.shtml 
UNHCR (2017) 'Mediterranean situation: Italy', available online at: https://data2.unhcr.org/en/situations/mediterranean/location/5205

Vassallo Paleologo, F. (2015) 'Ricorsi contro i dinieghi degli status di protezione ed effettività dei diritti di difesa', Tutmonda, 13 July, available online at: https://tutmonda.wordpress.com/2015/07/13/ricorsi-contro-i-dinieghi-degli-status-diprotezione-ed-effettivita-dei-diritti-di-difesa/

Verga, E. (2017) 'In Italia quella dei migranti è un'industria', Ilsole24ore.com, 7 June, available online at: http://www.econopoly.ilsole24ore.com/2017/06/07/in-italia-quella-dei-migrantiormai-e-unindustria-e-vale-oltre-4-miliardi/

Zaslove, A. (2006) 'The Politics of Immigration: A New Electoral Dilemma for the Right and the Left?' Review of the European and Russian Affairs, Vol. 2, no. 3, pp. 10-36.

Zincone, G. (2011), 'The Case of Italy', in Migration Policymaking in Europe: The Dynamics of Actors and Contexts in Past and Present, eds G. Zincone, R. Penninx \& M. Borkert, Amsterdam University Press, Amsterdam.

\footnotetext{
${ }^{1}$ They were approved by, respectively, the centre-left First Prodi Government (1996-98) and the centre-right Second Berlusconi Government (2001-05).

${ }^{2}$ http://www1.interno.gov.it/mininterno/export/sites/default/it/sezioni/sala_stampa/notizie/immigrazione/000073_201 1_04_06_accordo_Italia-Tunisia.html (last access: October 2017).

${ }^{3}$ The increased number of work permits in 2010 is also linked to the approximately 215,300 undocumented immigrant workers who were regularized in 2009.

${ }^{4}$ Since July 2017, we can observe a reduction in the number of unauthorized immigrants arriving on Italian shores (UNHCR 2017) as a result of the Libyan agreement. However, this closure has been accompanied by the opening of Tunisian and the Algerian routes as migrants and traffickers seek other ways to reach Italy (Carli 2017).

${ }^{5}$ We calculated and compared the results of all the surveys conducted by Eurobarometer from Spring 2007 to Fall 2016. All the surveys are available online at: http://ec.europa.eu/commfrontoffice/publicopinion/index.cfm

${ }^{6} \mathrm{M}$. Smith, '37\% of Britons say immigration has meant that where they live doesn't feel like home any more', available online at: https://yougov.co.uk/news/2016/12/05/many- europeans-say-immigration-has-meant-they-dont/, 5 December 2016.

${ }^{7}$ See the report by the organisation LasciateCIEntrare (2016).

${ }^{8}$ See media reports on the accusations against Moas (Malagutti \& Vergine dalla Valletta 2017) and Jugend Rettet (Camilli 2017).

${ }^{9}$ ECHR, Hirsi Jamaa and Others vs. Italy, Appl. No. 27765/09, 23 February 2012.

${ }^{10}$ ECHR, Tarakhel vs. Switzerland, Appl. No. 29217/12, 4 November 2014.

${ }^{11}$ Presidency of the Council of Ministers, Unified State-Regions Conference, Minutes no. 6/2011, Section of 30 March 2011.

${ }^{12}$ See the list of 'Member States' notifications of the temporary reintroduction of border control at internal borders pursuant to article 25 et seq. of the Schengen Border Code', available online at: https://ec.europa.eu/homeaffairs/what-we-do/policies/borders-and-visas/schengen/reintroduction-border-control_en.
} 
${ }^{13}$ Council Decision (EU) 2015/1533 of 14 September 2015 establishing provisional measures in the area of international protection for the benefit of Italy and of Greece.

${ }^{14}$ Communication from the Commission to the European Parliament and the Council on the State of Play of Implementation of the Priority Actions under the European Agenda on Migration', COM (2016) 85 final. 